\title{
The intake and excretion of calorific constituents of milk by babies*
}

\author{
By D. A. T. SOUTHGATE AND IRENE M. BARRETT $\dagger$ \\ Medical Research Council Department of Experimental Medicine, \\ University of Cambridge
}

(Received I3 September I965-Accepted I4 Fanuary I966)

\begin{abstract}
I. The intake and excretion of energy, total nitrogen, fat and carbohydrate by twenty baby boys aged about a fortnight were measured over 3 days. 2 . Ten of the babies received breast milk which had been expressed from their mothers, the remaining ten received one of two preparations based on dried cow's milk, with either lactose or sucrose added. 3 . The intake of energy, protein and carbohydrate was greater in the ten babies receiving the cow's milk preparations. 4 . The urinary excretion and retention of $\mathrm{N}$ was greater in the babies fed on the cow's milk preparations. 5. The absolute excretion of $\mathrm{N}$ in the faeces was similar whatever the diet, but the excretion of fat was less and the excretion of carbohydrate greater for babies having breast milk. 6 . The calorie: $\mathrm{N}$ ratio in the urine was $5.8 \mathrm{kcal} / \mathrm{g}$ urinary $\mathrm{N}$ in those receiving breast milk and $4.8 \mathrm{kcal} / \mathrm{g} \mathrm{N}$ in those fed on the cow's milk preparations. The value for the adult is $7 \cdot 9 \cdot 7$. Calorie conversion factors have been calculated which are more appropriate for milk diets for babies than the factors of Atwater which were designed for mixed diets for adults.
\end{abstract}

The calorific value of the milk consumed by a baby is usually calculated from the amounts of protein, fat and carbohydrate in the milk by the use of factors thought to represent the calorific value of these constituents to the human body. The calorie conversion factors of Atwater (Atwater, 1903) are generally used (Slater, 196r), although these factors were derived from experiments with adults and are applicable only to mixed diets (Maynard, 1944). The 'specific' calorie conversion factors for milk advocated by Merrill \& Watt (I955) are also based on experimental observations on adults.

Both the Atwater factors and the 'specific' calorie conversion factors for milk depend on values for the apparent digestibilities of the protein, fat and carbohydrate derived from observations on adults; the protein factor also includes a correction based on the calorie to nitrogen ratio in the urine of adults (Merrill \& Watt, 1955). Rubner \& Heubner's study (1898) of the energy balance of a breast-fed infant aged 9 weeks and the observations of Slater (I96I) suggest that the values for adults used by Atwater (1903) and Merrill \& Watt (1955) do not apply to the breast-fed infant. In addition, the method used for correcting the protein factor is theoretically valid only for a subject in nitrogen equilibrium, which a growing baby should never be (Widdowson, 1955).

The study to be described was undertaken to provide an experimental basis for more appropriate factors for calculating the energy value of a baby's diet.

* Part of the work described formed part of a thesis submitted by one of us (D.A.T.S.) to the University of London in partial fulfilment of the requirements for the degree of PhD.

$\dagger$ Present address: Human Nutrition Research Unit, Mill Hill, London. 


\section{EXPERIMENTAL}

\section{The subjects}

Twenty baby boys aged about 2 weeks were studied. During the course of the study they lived with their mothers in a home in Cambridge. Two nurses from the Department of Experimental Medicine were responsible for measuring the intake of milk and the collection of urine and faeces.

Ten babies received breast milk and the other ten one of two preparations based on dried milk. One was a proprietary preparation which contained added lactose and the other a dried milk to which sucrose was added during the preparation of the feeds.

The ages and weights of the babies and the length of the studies are summarized in Table $\mathrm{I}$.

Table I. Number, ages and weights of babies receiving breast milk or a cow's milk preparation

\begin{tabular}{|c|c|c|c|c|c|}
\hline & (Mea & alues anc & inges) & & \\
\hline & & & Weig & $(\mathrm{kg})$ & \\
\hline Type of milk given & $\begin{array}{l}\text { No. of } \\
\text { babies }\end{array}$ & $\begin{array}{c}\text { Age } \\
\text { (days) }\end{array}$ & $\begin{array}{l}\text { At start } \\
\text { of } \\
\text { experiment }\end{array}$ & $\begin{array}{c}\text { At end } \\
\text { of } \\
\text { experiment }\end{array}$ & $\begin{array}{c}\text { Duration } \\
\text { of study } \\
\text { (h) }\end{array}$ \\
\hline Breast milk & ro & $\begin{array}{c}1_{3} \\
(11-17)\end{array}$ & $\begin{array}{c}3.59 \\
(3 \cdot 12-4 \cdot r 9)\end{array}$ & $\begin{array}{c}3 \cdot 67 \\
(3 \cdot 22-4 \cdot 30)\end{array}$ & 68 \\
\hline $\begin{array}{l}\text { Cow's milk preparation with } \\
\text { added lactose }\end{array}$ & 5 & $\begin{array}{c}16 \\
(12-22)\end{array}$ & $\begin{array}{c}3.51 \\
(2 \cdot 91-4.06)\end{array}$ & $\begin{array}{c}3.65 \\
(3.07-4 \cdot 06)\end{array}$ & 72 \\
\hline $\begin{array}{l}\text { Cow's milk preparation with } \\
\text { added sucrose }\end{array}$ & 5 & $\underset{(\mathrm{II}-\mathrm{I} 5)}{\mathrm{T} 4}$ & $\begin{array}{c}3 \cdot 55 \\
(3 \cdot 19-3 \cdot 79)\end{array}$ & $\begin{array}{c}3 \cdot 74 \\
\left(3 \cdot 3^{6}-4^{\circ} \cdot 06\right)\end{array}$ & 72 \\
\hline
\end{tabular}

\section{Measurement of intake}

The breast milk was expressed into a container and well mixed; a sample was taken for analysis and the remainder fed to the baby from a bottle. The babies were fed from bottles in order to obtain an accurate value for the intake of fat, which is difficult to obtain from a random sample because of the variation in the fat content of the milk during the course of emptying the breast (Gunther \& Stanier, I95I). The intake was taken as the difference between the weights of the bottle at the beginning and end of feeding.

The intake of the milk preparations was measured in a similar way, and a small sample taken for analysis at each feeding time. The individual samples were pooled in the correct proportions to provide an overall sample of milk representing the intake over the period studied.

Regurgitated milk was collected on nylon bibs, from which it was washed off and analysed. The amount regurgitated was deducted from the intake as measured above.

\section{Collection and preparation of the excreta}

The methods described by Slater (I96I) were used, except that muslin napkins were used instead of nylon ones. The faecal homogenate was not acidified and samples 
were taken for analysis before the homogenate was concentrated. The remainder of the faecal homogenate was dried on a water-bath and then under reduced pressure over $\mathrm{P}_{2} \mathrm{O}_{5}$ until a brittle mass was obtained.

\section{Analytical methods}

Heat of combustion. The heats of combustion of the milks, urines and faeces were measured in an adiabatic bomb calorimeter (Gallenkamp Ltd). The milks and urines were freeze-dried before combustion. The urines were very dilute and sometimes it was necessary to add a known amount of benzoic acid to the urine solids in order to obtain a satisfactory rise in temperature. The faecal solids were combusted without further treatment.

Total nitrogen. Total $\mathrm{N}$ was measured by the micro-Kjeldahl method using the catalyst and technique of Chibnall, Rees \& Williams (r943).

Fat. This was measured in both milks and faeces by a modification of von Lieberman \& Szekely's (I 898) method in which the fatty acids were estimated gravimetrically.

Carbohydrate. Lactose was measured in the milk sample as described by Slater (196I) after deproteinization with $\mathrm{NaOH}$ and $\mathrm{ZnSO}_{4}$ (Somogyi, 1945). Sucrose was measured as the increase in the reducing sugars after inversion with $\mathrm{HCl}$ at room temperature following conditions described by the Association of Official Agricultural Chemists (1950).

Carbohydrates were measured in the faeces by adding sufficient ethanol to produce an $80 \%(\mathrm{v} / \mathrm{v})$ faecal homogenate. The mixture was filtered and reducing sugars were measured after removal of the alcohol at low temperature. Semi-quantitative paper chromatography was used to identify the sugars present and to estimate the correct reduction equivalents to be used.

Paper chromatography. This was used for the identification of sugars in the faecal homogenate. The descending method was used with Whatman no. I paper, ethyl acetate: acetic acid: water $(3: 1: 3)$ as the solvent and aniline phthalate as the spraying reagent for detecting sugars (Partridge, 1949).

Nitrogenous compounds in the urine. Urea was measured colorimetrically by reaction with $p$-dimethyl-aminobenzaldehyde. This reaction has been used by Delcourt (1959) and Brown (1959), but the procedure used by us differed from that described by these authors. The reaction was carried out in glass-stoppered tubes. To I $\mathrm{ml}$ of urine were added $3 \mathrm{ml}$ water and $4 \mathrm{ml}$ methanol; after mixing, I $\mathrm{ml}$ of a solution of $p$-dimethyl-aminobenzaldehyde $(0.8 \mathrm{~g}$ dissolved in $30 \mathrm{ml}$ methanol and $30 \mathrm{ml}$ conc. $\mathrm{HCl}$ ) was added and the contents of the tube were mixed. The extinction of the solution was measured at $420 \mathrm{~nm}$ against distilled water. A urine blank, a reagent blank and standard amounts of urea were carried through the entire procedure. The colour produced obeyed Beer's law over the range of concentration of o-1o mg urea per $\mathrm{ml}$ and uric acid, creatinine, hippuric acid and tryptophan gave no colour even at the same concentration as urea in normal adult urine. The substance in urine reacting with the reagent under the conditions described was completely absent after treatment with urease (British Drug Houses Ltd).

Ammonia was measured by distillation into boric acid after adjusting the $\mathrm{pH}$ of the 
urine to $6 \cdot 8$, with phenol red as indicator, and creatinine by the modification of Folin's method described by Hawk, Oser \& Summerson (1954). Uric acid was measured by a modification of the method of Benedict $\&$ Franke (1922) in which the mode of addition and mixing of the reagents was rigidly standardized, this modification was found to improve the reproducibility and sensitivity of the method.

\section{RESULTS}

\section{Energy balances}

Table 2 gives the mean values, with their standard deviations, for the heats of combustion of the intake and the urinary and faecal excretions of the babies receiving each of the three types of milk. The table also shows the combined values for the ten babies having the cow's milk preparations.

The gross energy value of the intake was higher for the babies having the cow's milk preparations. The loss of calorific material in the urine in the babies fed on breast milk was only $0.7 \%$ of the gross intake as against $\mathrm{I} \cdot 3 \%$ for the babies in the other groups. The faecal loss amounted to about $7 \%$ of the intake, whatever the type of milk.

\section{Table 2. Energy balances of babies fed on breast milk or cow's milk preparations}

(kcal/24 $\mathrm{h} \mathrm{kg}$ body-weight; mean values with standard deviations)

\begin{tabular}{|c|c|c|c|c|c|c|}
\hline Type of milk & Intake & Urine & Faeces & $\begin{array}{l}\text { Digestible } \\
\text { energy }\end{array}$ & $\begin{array}{c}\text { Meta- } \\
\text { bolizable } \\
\text { energy }\end{array}$ & $\begin{array}{c}\text { Metabolizable } \\
\text { energy } \\
\text { ( } \% \text { of } \\
\text { intake) }\end{array}$ \\
\hline Breast milk & I $15 \pm 7$ & $0.8 \pm 0.3$ & $8 \cdot 5 \pm 3.0$ & $106 \pm 7$ & $105 \pm 7$ & $91 \cdot 8 \pm 2.69$ \\
\hline $\begin{array}{l}\text { Cow's milk preparation with } \\
\text { added lactose }\end{array}$ & $133 \pm 16$ & $x \cdot 8 \pm 0 \cdot 9$ & $9 \cdot 4 \pm 2 \cdot 7$ & $124 \pm 14$ & $122 \pm 14$ & $9 r \cdot 7 \pm 2 \cdot 38$ \\
\hline $\begin{array}{l}\text { Cow's milk preparation with } \\
\text { added sucrose }\end{array}$ & $137 \pm 12$ & $I \cdot 5 \pm 0.7$ & $9 \cdot 4 \pm \mathbf{I} \cdot 8$ & I $28 \pm$ I I & I26 \pm I I & $92 \cdot 1 \pm 0.73$ \\
\hline $\begin{array}{l}\text { Cow's milk preparations: } \\
\text { combined results }\end{array}$ & $135 \pm$ I 3 & $x \cdot 7 \pm 0 \cdot 8$ & $9 \cdot 4 \pm 2 \cdot 2$ & $126 \pm 12$ & $124 \pm 12$ & $9 I \cdot 9 \pm I \cdot 43$ \\
\hline
\end{tabular}

The metabolizable energy, that is the difference between the gross intake and the losses in the excreta, was greater for the babies on the cow's milk preparations; but expressed as a percentage of the gross intake it was the same with all three milks.

\section{Intake and excretion of calorific constituents}

The mean values for the intake and excretion of total $\mathrm{N}$, fat and carbohydrate are given in Table 3 .

Total $N$. The intake of total $\mathrm{N}$ by the babies receiving breast milk was approximately half that of those having the cow's milk preparations. The urinary excretion was also correspondingly lower in the group fed on breast milk but the amount of $\mathrm{N}$ excreted in the faeces was much the same whatever the type of milk. The absolute retention of $\mathrm{N}$ was considerably greater in the babies having the cow's milk preparations.

Fat. The intake of fat was higher in the babies fed on breast milk and the faecal 
Vol. 20

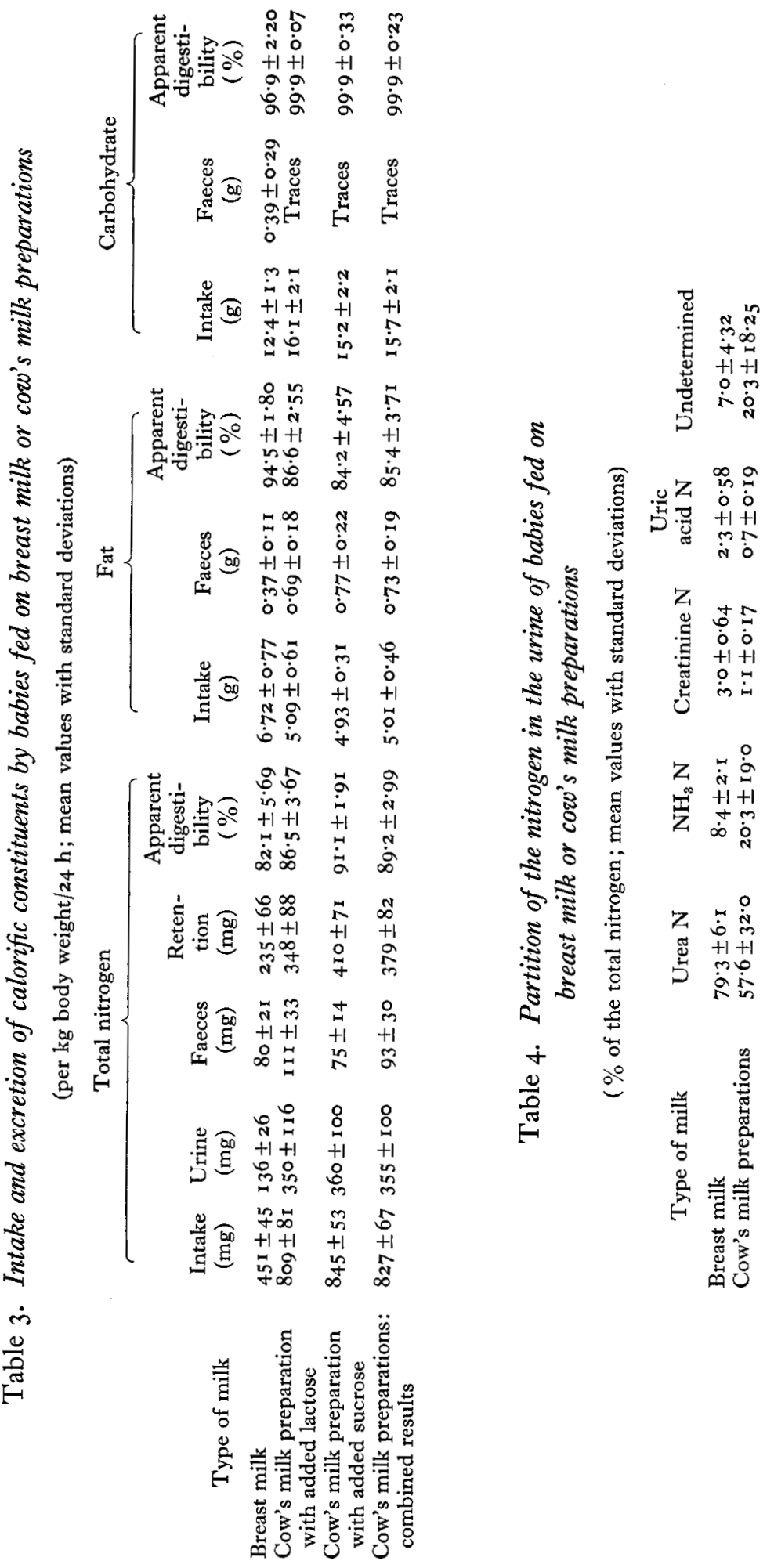


excretion lower. The difference between the faecal excretion on breast milk and on the cow's milk preparations was highly significant $(t=5 \cdot 1, P<0.001)$.

Carbohydrates. Only traces of sugars were present in the faeces of the babies having the cow's milk preparations, whereas the faeces of the group fed on breast milk contained appreciable amounts of lactose and galactose, and always had an aroma of caramel when dried.

\section{Composition of the urinary nitrogenous material}

The mean values for the partition of the urinary $N$ are given in Table 4 ; the two cow's milk preparations are considered together because there were no differences between them.

The contributions of ammonia $\mathrm{N}$ and undetermined $\mathrm{N}$ were higher in the babies having the cow's milk preparations. This had the effect of reducing the percentage of urea $\mathrm{N}$, but in spite of this the total excretion of urea was higher because of the higher protein intake.

\section{DISCUSSION}

\section{Comparison of breast milk and the cow's milk preparations}

The results obtained extend the finding of Slater (I96r) with babies I week old in showing a greater intake, urinary excretion and retention of $\mathrm{N}$ by babies receiving preparations based on cow's milk. In this study the intake of breast milk may have been depressed by giving it from a bottle, but the babies were fed to capacity. The 3-day period studied was probably too short to attach any great significance to any correlation between the retention of $\mathrm{N}$ and the gain of weight. Nevertheless, the mean gains of weight, 80,140 and $190 \mathrm{~g}$ respectively were almost proportional to the respective $\mathrm{N}$ retentions of $2 \cdot 33,3.88$ and $4.38 \mathrm{~g}$. This is equivalent to about $35 \mathrm{~g}$ live weight gain per $\mathrm{g} \mathrm{N}$ retained, which would provide protein concentration in the new tissues of about $18 \%$, a value that may be regarded as reasonable (Widdowson \& Spray, 195I).

The breast milk provided fewer calories per $\mathrm{kg}$ per $24 \mathrm{~h}$ than the cow's milk preparations and the percentages of the total energy intake supplied by the three main components were different. The energy from protein was $13 \%$ for the babies fed on breast milk and $22 \cdot 1 \%$ for those fed on the cow's milk preparations. The contribution from fat was also very different being 49.6 and $34.4 \%$ respectively for the two types of milk.

Table 3 shows the mean values for the apparent digestibilities of the protein, fat and carbohydrate in the milks expressed as percentages of the intake.

The values for protein are close to those reported by Slater (1961), and the value for breast milk agrees well with that of $83 \cdot 1 \%$ reported by Rubner $\&$ Heubner ( 1898 ). Taken at their face value these results suggest that the baby 'digests' the proteins in cow's milk better than those in breast milk. The values for the faecal excretion of $\mathrm{N}$, however, show that the faecal loss was approximately the same with all three milks. This suggests that the $\mathrm{N}$ in the faeces was independent of the intake and consisted of endogenous losses and bacterial material and was not dependent to any material extent 
upon the excretion of undigested dietary protein. Slater (I96I) also found a similar faecal excretion in her two groups of babies, as did Widdowson (1965), and McCance \& Widdowson (1947) made a similar observation on adults.

The value for the apparent digestibility of the fat in breast milk was of the same order as that found for adults eating a mixed diet; on the other hand, the value for the cow's milk preparations was much lower than that normally observed for adults.

The digestibility of various fats by infants was investigated by Holt, Tidwell, Kirk, Cross \& Neale (1935), who came to the conclusion that the chain length and the degree of saturation of the component fatty acids were important in determining the digestibility of a fat. The differences between the digestibility of the fat in the cow's milk preparations and that in breast milk may be due to differences of this sort, because Ocklitz \& Reinmuth (1959) and Schreier (1958) found that the absorption of fat improved with a rise in the percentage of unsaturated fatty acids. The problem has been discussed recently by Widdowson (1965), who expressed the opinion that properties other than the chain length or the degree of saturation may also be involved.

The greater excretion of carbohydrate in the faeces of babies fed on breast milk also presents a paradox, since babies receiving the cow's milk preparation with added lactose had no lactose in their stools despite their greater intake. This difference may be due to the effect of other constituents on the digestibility of lactose, but is more probably due to differences in the intestinal microflora (Barbero, Runge, Fischer, Crawford, Torres \& György, 1952; Feldheim, 1958; Dehnert, 1960). Lactose is fermented by only a few strains of Lactobacillus bifidus, the organism which usually makes up the major part of the intestinal flora of the breast-fed infant. The results suggest that lactose is normally incompletely absorbed in the small intestine of the young baby and that with the babies fed on cow's milk preparations the microorganisms in the large intestine are responsible for metabolizing the remainder. It would also appear that the glucose portion of the lactose molecule is preferentially metabolized by the organisms present. The inability to absorb lactose exhibited by infants in some pathological conditions (Holzel, I964) may thus be found to a very slight extent in young normal infants.

\section{The calorie to $N$ ratio in urine}

Rubner \& Heubner ( 1898 ) found a calorie to $\mathrm{N}$ ratio of over $12 \mathrm{kcal} / \mathrm{g} \mathrm{N}$ in the urine of the 9-week-old child they studied (Widdowson, 1955), which may be compared with the mean value for adults found by Atwater (Merrill \& Watt, 1955) of $7.9 \mathrm{kcal} / \mathrm{g} \mathrm{N}$.

The ratios found in the study now presented were $5.8 \mathrm{kcal} / \mathrm{g} \mathrm{N}$ in the urine of the babies having breast milk and $4.8 \mathrm{kcal} / \mathrm{g} \mathrm{N}$ for the babies having the cow's milk preparations. It was impossible to calculate a theoretical calorie: $N$ ratio from the partition of the urinary $\mathrm{N}$ and the heats of combustion of the various constituents, because of the presence of the relatively large proportion of undetermined nitrogenous material.

The high value reported by Rubner \& Heubner (1898) may have been due to the excretion of non-nitrogenous organic matter in the urine or to a large excretion of 
amino acids. The absence of any gain in weight by the child and the low intake of $\mathrm{N}$ compared with those of the babies in our study may well indicate that the child was not completely normal.

\section{The derivation of calorie conversion factors for the calculation of the} metabolizable energy of babies' food intake

The principles which Atwater followed when deriving his classical calorie conversion factors have been reviewed on several occasions (Morey, I936-7; Maynard, I944; Merrill \& Watt, I955; Widdowson, I955). They were derived for the calculation of the metabolizable energy of a diet from the amounts of protein, fat and carbohydrate that it contains.

Table 5. Derived calorie conversion factors appropriate to the milks studied compared with the factors for adults

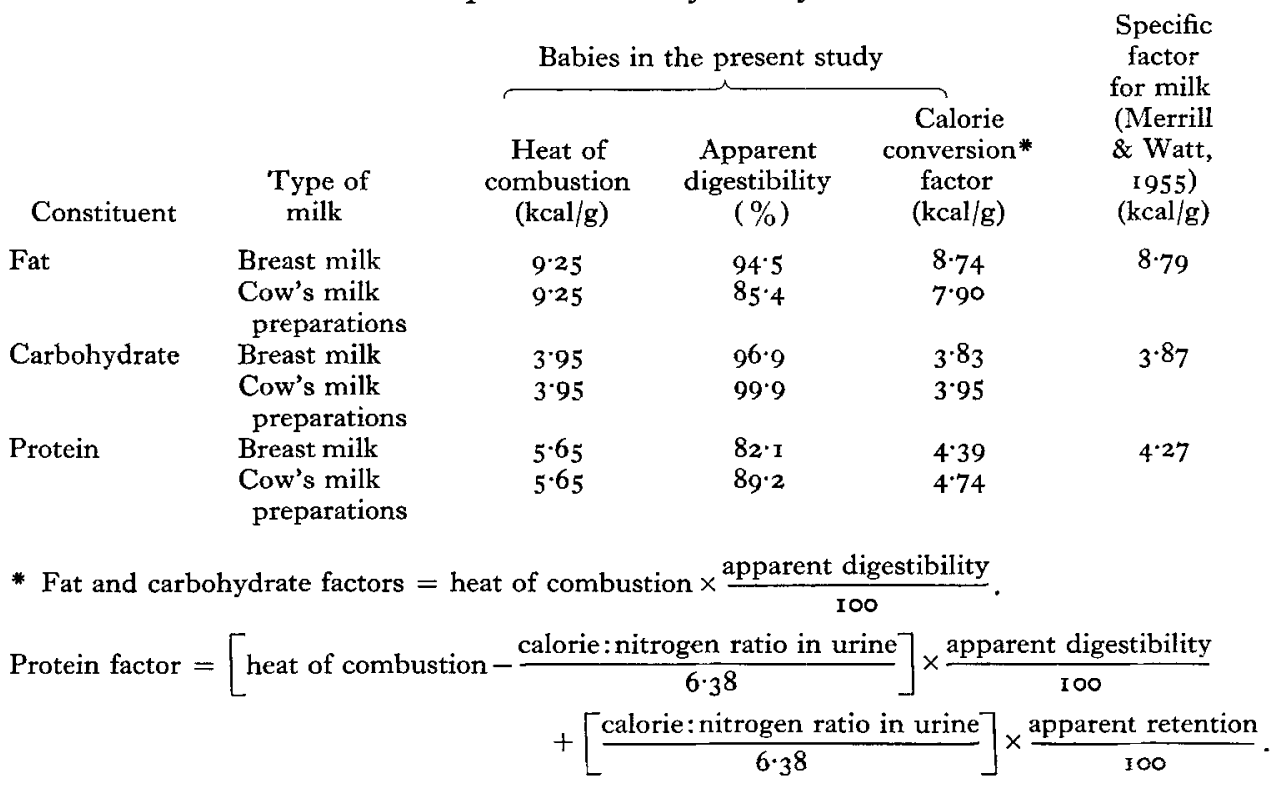

Metabolizable energy may be defined (Blaxter \& Graham, I955) as the difference between the gross energy intake (the heat of combustion of the diet) and the heats of combustion of the urinary and faecal excretions and, strictly, of any other losses of energy in secretions or intestinal gases. In these studies, as in most human metabolic studies, the losses in secretions and intestinal gases have been ignored as they are probably small and certainly very difficult to measure.

In Atwater's terminology (Atwater, I900) this is the available energy of the diet; that is energy that is available for work, the maintenance of body temperature or for storage in new tissues during the course of growth or repair.

Each of the three Atwater factors includes a term for the heat of combustion and the apparent digestibility of the constituent. The factor for protein includes an additional term to allow for the loss of energy in the urine. This 'urinary correction' 
was based on the ratio of calories to $\mathrm{N}$ in the urine (Merrill \& Watt, I955), it is only valid if the subject is in $\mathrm{N}$ equilibrium which is not so with the growing infant deriving more energy from each gram of ingested protein by virtue of the proportion retained in the new tissues. The retention of protein may not provide a source of energy for work or for the maintenance of body temperature (Widdowson, 1955), but this energy is properly included in the metabolizable energy of the diet until it is possible to implement some of the suggestions of Keys (1945) with regard to the actual metabolic fate of the different dietary constituents.

Table 5 shows the derivation of calorie conversion factors for breast milk and the cow's milk preparations based on our experimental results. In the derivation of the protein factor shown in this table 'apparent retention' is defined by analogy to apparent digestibility, that is apparent retention $=$ intake - total excretion expressed as a percentage of intake. The table also gives the factors for milk proposed by Merrill \& Watt (I955), for comparison, although these values are intended to apply only to adults. The factors differ in detail from those proposed by Merrill \& Watt (1955), especially those for protein and fat in cow's milk preparations. Calculations using the derived factors and the specific factors show only slight differences between the metabolizable energy calculated in the two ways. This agreement, however, is a coincidence and is a characteristic of all calculations involving calorie conversion factors (Widdowson, I96I).

The studies presented here show that the calorie conversion factors for the milk taken by young babies should not be derived from observations on adults and that the derivation of any series of factors must make allowance for the physiological differences between the young animal and the adult (McCance \& Widdowson, 1957).

The skill and patience of Miss P. Hennessey and Miss S. Dean, the departmental nurses are gratefully acknowledged. Miss G. A. Norden gave valuable assistance in the chemical estimations, and Miss M. Friskey from the Department of Applied Physiology, University of Glasgow carried out the bomb calorimetric determinations. The authors would also like to thank the mothers and their sons without whom this study would have been impossible, and the matron of the home for her valuable cooperation. Professor R. A. McCance and Dr E. M. Widdowson gave valuable advice and encouragement in this work.

\section{REFERENCES}

Association of Official Agricultural Chemists (1950). Official Methods of Analysis, 7th ed., p. 503. Washington, DC: Association of Official Agricultural Chemists.

Atwater, W. O. (1900). 12th Rep. Storrs agric. Exp. Stn.

Atwater, W. O. (1903). 15th Rep. Storrs agric. Exp. Stn.

Barbero, G. J., Runge, G., Fischer, D., Crawford, M. N., Torres, F. E. \& György, P. (1952). 7 . Pediat. 40, 152.

Benedict, S. R. \& Franke, E. (1922). 7. biol. Chem. 52, 387.

Blaxter, K. L. \& Graham, N. McC. (1955). Proc. Nutr. Soc. 14, 132.

Brown, H. H. (1959). Analyt. Chem. 31, I844.

Chibnall, A. C., Rees, M. W. \& Williams, E. F. (1943). Biochem. F. 37, 354.

Dehnert, J. (г 960). Z. Kinderheilk. 83, 332.

Delcourt, R. (1959). Revue belge Path. Méd. exp. 27, 50.

Feldheim, G. (1958). Ernährungsforschung, 8, I93. 
Gunther, M. \& Stanier, J. E. (195I). Spec. Rep. Ser. med. Res. Coun., Lond., no. 275, p. 379.

Hawk, P. B., Oser, B. L. \& Summerson, W. H. (1954). Practical Physiological Chemistry, I3th ed. London: J. and A. Churchill.

Holt, L. E. Jr., Tidwell, H. C., Kirk, C. M., Cross, D. M. \& Neale, S. (1935). F. Pediat. 6, 427.

Holzel, A. (1 964). Proc. Nutr. Soc. 23, 123.

Keys, A. (1945). F. Nutr. 29, 8I.

Maynard, L. A. (1944). F. Nutr. 28, 443.

McCance, R. A. \& Widdowson, E. M. (1947). F. Hyg., Camb., 45, 59.

McCance, R. A. \& Widdowson, E. M. (r957). Lancet, ii, 585 .

Merrill, A. L. \& Watt, B. K. (1955). Agric. Handbook, U.S. Dep. Agric. no. 74.

Morey, N. B. (1936-7). Nutr. Abstr. Rev. 6, I.

Ocklitz, H. W. \& Reinmuth, B. (1959). Z. Kinderheilk. 82, 321.

Partridge, S. M. (1949). Nature, Lond., r64, 443.

Rubner, M. \& Heubner, O. (1898). Z. Biol. 36, 1.

Schreier, K. (1958). Z. Kinderheilh, 81, 442.

Slater, J. E. (1961). Br. $\mathscr{F}$. Nutr. $\mathbf{r}_{5}, 83$.

Somogyi, M. (1945). F. biol. Chem. r6o, 69.

von Lieberman, L. \& Szekely, S. (1898). Pflügers Arch. ges. Physiol. 72, 336.

Widdowson, E. M. (1955). Proc. Nutr. Soc. 14, 142.

Widdowson, E. M. (r961). Spec. Rep. Ser. med. Res. Coun., Lond., no. 297, p. I 53.

Widdowson, E. M. (1965). Lancet, ii, 1099.

Widdowson, E. M. \& Spray, C. M. (195I). Archs. Dis. Childh. 26, 205. 